\title{
Determinants of exercise capacity in cystic fibrosis patients with mild-to-moderate lung disease
}

\author{
Jean Pastré ${ }^{1}$, Anne Prévotat ${ }^{1}$, Catherine Tardif², Carole Langlois ${ }^{3}$, Alain Duhamel ${ }^{3}$ and Benoit Wallaert ${ }^{*}$
}

\begin{abstract}
Background: Adult patients with cystic fibrosis (CF) frequently have reduced exercise tolerance, which is multifactorial but mainly due to bronchial obstruction. The aim of this retrospective analysis was to determine the mechanisms responsible for exercise intolerance in patients with mild-to-moderate or severe disease.

Methods: Cardiopulmonary exercise testing with blood gas analysis at peak exercise was performed in 102 patients aged $28 \pm 11$ years: 48 patients had severe lung disease ( $\mathrm{FEV}_{1}<50 \%$, group 1) and 54 had mild-to-moderate lung disease ( $\mathrm{FEV}, \geq 50 \%$, group 2). $\mathrm{VO}_{2}$ peak was measured and correlated with clinical, biological, and functional parameters.

Results: $\mathrm{VO}_{2}$ peak for all patients was $25 \pm 9 \mathrm{~mL} / \mathrm{kg} / \mathrm{min}(65 \pm 21 \%$ of the predicted value) and was $<84 \%$ of predicted in $82 \%$ of patients ( $100 \%$ of group $1,65 \%$ of group 2). $\mathrm{VO}_{2}$ peak was correlated with body mass index, C-reactive protein, $\mathrm{FEV}_{1}, \mathrm{FVC}$, RV, DLCO, $\mathrm{V}_{\mathrm{E}} N \mathrm{NCO}_{2}$ peak, $\mathrm{V}_{\mathrm{D}} \mathrm{N}_{\mathrm{T}}, \mathrm{PaO}_{2}, \mathrm{PaCO}_{2}, \mathrm{P}(\mathrm{A}-\mathrm{a}) \mathrm{O}_{2}$, and breathing reserve. In multivariate analysis, $\mathrm{FEV}_{1}$ and overall hyperventilation during exercise were independent determinants of exercise capacity $\left(R^{2}=0.67\right)$. $F E V_{1}$ was the major significant predictor of $\mathrm{VO}_{2}$ peak impairment in group 1 , accounting for $31 \%$ of $\mathrm{VO}_{2}$ peak alteration, whereas excessive overall hyperventilation (reduced or absent breathing reserve and $\mathrm{V}_{\mathrm{E}} \mathrm{NCO}_{2}$ ) accounted for $41 \%$ of $\mathrm{VO}_{2}$ alteration in group 2.
\end{abstract}

Conclusion: Exercise limitation in adult patients with $\mathrm{CF}$ is largely dependent on $\mathrm{FEV}_{1}$ in patients with severe lung disease and on the magnitude of the ventilatory response to exercise in patients with mild-to-moderate lung disease.

Keywords: Cystic fibrosis, Cardiopulmonary exercise testing, Pulmonary function, Exercise

\section{Background}

Cystic fibrosis (CF) is characterized by deterioration of nutritional status and irreversible loss of lung function [1-3]. Patients with CF often experience exertional dyspnea and have reduced maximal exercise capacity, which is an important predictor of mortality [4-7]. Regular exercise in these patients has been associated with improved aerobic exercise endurance and quality of life $[4,8]$. Physical exercise requires the cardiopulmonary system to deliver oxygen to muscles in sufficient quantity to generate energy through aerobic glycolysis. There are conflicting data on the precise mechanisms

\footnotetext{
* Correspondence: benoit.wallaert@chru-lille.fr

${ }^{1}$ Université Lille 2 et Clinique des Maladies Respiratoires, CRCM Hôpital Calmette, CHRU Lille, France

Full list of author information is available at the end of the article
}

underlying exercise intolerance in $\mathrm{CF}$, and a number of factors have been implicated [9], including poor nutritional status, peripheral muscle dysfunction $[10,11]$, and especially, ventilatory limitation $[12,13]$. In other studies, dysfunctional gas exchange has been shown to play a crucial role in limiting exercise performance [14-17].

Only a third of the variability in exercise capacity of $\mathrm{CF}$ patients can be explained by $\mathrm{FEV}_{1}$, demonstrating that resting pulmonary function tests (PFTs) alone are insufficient to explain the exercise limitation $[1,9,13]$. By comparison, cardiopulmonary exercise testing (CPET) offers a sensitive evaluation of potential physiological disturbances in cardiovascular, respiratory, peripheral, or neurosensory responses to a standardized exercise protocol [18]. Although it remains underutilized in CF [19], CPET could provide important exercise-related

\section{Biomed Central}

(c) 2014 Pastré et al.; licensee BioMed Central Ltd. This is an Open Access article distributed under the terms of the Creative Commons Attribution License (http://creativecommons.org/licenses/by/2.0), which permits unrestricted use, distribution, and reproduction in any medium, provided the original work is properly credited. 
measures that might explain the reduced exercise performance and thus assist in CF patient management aimed at improving exercise capacity.

With this in mind, we initiated a study to determine the mechanisms responsible for exercise limitation in 102 adult CF patients with mild-to moderate or severe lung disease. The patients were subjected to CPET with blood gas analysis during exercise and the results were correlated with clinical and functional characteristics.

\section{Methods}

\section{Patients}

A total of 102 adult patients (sex ratio M:F 0.52) with CF were enrolled at four CF centers in France: Lille (75 patients), Rouen (15 patients), Dijon (5 patients), and Grenoble (7 patients). Written informed consent for participation in the study was obtained from participants. Use of the patient data was approved by the local ethics committee, and the study was considered observational and approved as such by the Institutional Review Board of the French Learned Society for Pulmonology (Société de Pneumologie de Langue Française, CEPRO 2012 009).

Clinical, nutritional, biological, PFT, and CPET data were obtained on the same day, either at diagnosis or at the routine annual evaluation, and were retrospectively collected. When patients were seen at several follow-up visits, only the data from the first visit were recorded. Hypoxemic patients did not perform CPET and were excluded from the analysis. A diagnosis of CF was obtained by sweat chloride $>60 \mathrm{mmol} / \mathrm{L}$ and the presence of CFTR gene mutations by molecular analysis. Additional characteristics recorded at the time of testing were diseases usually associated with CF, bacterial colonization, treatments, and nutritional status, including height and weight measurements and impedance analysis.

\section{Cardiopulmonary testing}

Forced vital capacity (FVC), forced expiratory volume in $1 \mathrm{~s}\left(\mathrm{FEV}_{1}\right), \mathrm{FEV}_{1}$ to FVC ratio, total lung capacity (TLC), and residual volume (RV) were measured by plethysmography (Jaeger-Masterlab ${ }^{\oplus}$ cabin). Diffusing capacity of the lung for carbon monoxide (DLCO: $\mathrm{mL} \mathrm{CO} / \mathrm{min} / \mathrm{mm} \mathrm{Hg}$ ) was adjusted for hemoglobin concentration in $\mathrm{g} / \mathrm{dL}$ according to Cotes' equation: corrected (Hb) DLCO = $\mathrm{DLCO} \times(10.2+\mathrm{Hb}) /(1.7 \times \mathrm{Hb})$. Following ATS/ERS 2005 guidelines, the lower limits of normal were set at the 5 th percentile (or predicted minus 1.64 SD) of each reference population. The results are expressed as percentages of the predicted values. Predicted normal values were derived from standard equations [20-22].

PFTs and CPET were performed in an air-conditioned laboratory $\left(22^{\circ} \mathrm{C}\right.$ constant temperature), using a standardized protocol as previously described [23,24]. The
CPET protocol was the same at each center. Each patient underwent a symptom-limited incremental exercise test on an ergometric bicycle (Ergoline-Ergometrics $800^{\circ}$ ). The protocol included a warm-up period of $3 \mathrm{~min}$ at $20 \mathrm{~W}$ followed by a progressively increasing work rate (WR) in a ramp fashion and then 3 min recovery. The ramped WR increment was individualized (range, 8-30 W/min). During exercise, heart rate (HR) was monitored continuously by 12-lead ECG, and arterial oxygen saturation $\left(\mathrm{SpO}_{2}\right)$ was measured by pulse oximetry (Nellcor N-395). The expired gases were analyzed with an Ergocard ${ }^{\oplus}$, focusing on oxygen consumption $\left(\mathrm{VO}_{2}\right)$, carbon dioxide production $\left(\mathrm{VCO}_{2}\right)$, minute ventilation (VE), and tidal volume (VT). The oxygen pulse $\left(\mathrm{VO}_{2} / \mathrm{HR}\right)$ was calculated. Measurements of $\mathrm{PaO}_{2}$ and $\mathrm{PaCO}_{2}$ were performed on room air at rest and at peak exercise. Normal values for $\mathrm{PaO}_{2}$ were derived from [25]. Lactatemia was determined at maximal exercise. Breathing reserve $(\mathrm{BR})$ was calculated as $\mathrm{BR}=$ (predicted maximum minute ventilation $[\mathrm{MMV}]-\mathrm{V}_{\mathrm{E}}$ peak)/MMV, with $\mathrm{MMV}$ estimated from $\mathrm{MMV}=\mathrm{FEV}_{1} \times 40$. HR peak was expressed as a percentage of maximum predicted HR, calculated as HR $\max =210-(0.65 \times$ age $)$. Dead space $\left(V_{D} / V_{T}\right)$ was calculated according to Bohr's equation corrected for the additional instrument dead space: $\mathrm{V}_{\mathrm{D}} / \mathrm{V}_{\mathrm{T}}=\left(\mathrm{PaCO}_{2}-\mathrm{PECO}_{2}\right.$ mean $) / \mathrm{PaCO}_{2}-\left(\mathrm{V}_{\mathrm{D}}\right.$ [machine $] /$ $\mathrm{V}_{\mathrm{T}}$ ) where $\mathrm{PECO}_{2}$ is the partial pressure of expired $\mathrm{CO}_{2}$. Predicted values for $\mathrm{VO}_{2}$ max were calculated from reference equations [26]. Poor motivation appeared not to be an interfering factor in our analysis, as all patients had at least one of the following: $\mathrm{BR}<15 \%$, peak $\mathrm{HR}>90 \%$ of predicted, peak lactate $>7 \mathrm{mmol} / \mathrm{L}$, peak exercise $\mathrm{PaO}_{2}<55 \mathrm{~mm} \mathrm{Hg}$, and peak $\mathrm{V}_{\mathrm{E}} / \mathrm{VO}_{2}>35$ or peak RER $>$ 1.15 [23]. Immediately after exercise, subjects were asked to score their sense of breathlessness and muscle fatigue at peak exercise using Borg scales.

\section{Statistical analysis}

The continuous variables are reported as mean \pm SD. Normal distribution of quantitative variables was tested by the Shapiro-Wilk test. Differences in $\mathrm{FEV}_{1}$ between the groups were determined with the Student's t-test or Mann-Whitney test. Bivariate analyses were performed to study the relationships between each explanatory variable and the VO2 peak. Pearson's or Spearman's correlation coefficient was used for quantitative variables, and the Student's t-test or Mann-Whitney test for qualitative variables. In addition, a multivariable linear regression with a stepwise selection at the level 0.2 was performed to identify a subset of the most important explanatory variables for the relationship with VO2 peak. In order to avoid the problem of multicolinearity which happens when the explanatory variables are highly correlated, and to obtain a parsimonious model, we adopt the 
following strategy: first, variables with $\mathrm{p}<0.2$ were selected and included in a Principal Component Analysis (PCA) in order to study their correlations. Then, the variables included in the multivariable regression model were selected by the results of PCA (graphic correlation circle) on the basis of their clinical pertinence. The stability of the model was assessed by a bootstrap method [27]. The bootstrap resampling method was based on 1000 replicates of the initial dataset. Multivariable regression with a stepwise selection at the level 0.2 was performed on each of these replicates. The inclusion of the variable in the final model was confirmed if this candidate variable was selected in at least $70 \%$ of these 1000 analyses. In the final model, for each variable we computed the partial R-square, coefficient, 95\% confidence intervals and adjusted $\mathrm{p}$-value. Final variables from the multivariate analysis were applied to each group of $\mathrm{FEV}_{1}$. All analyses were achieved with SAS software version 9.2 (SAS Institute Inc., Cary, NC). All tests were performed at the significant level at 0.05 .

\section{Results}

Subjects

The demographic and clinical characteristics are shown in Table 1, and the resting PFT results are presented in Table 2. The cohort consisted of $102 \mathrm{CF}$ patients with a mean age of $28 \pm 11$ years (range 17-67). The time from diagnosis to evaluation was $16 \pm 10$ years. For data analysis, the cohort was divided into two groups according to

\section{Table 1 Demographic and clinical characteristics of the} CF patients

\begin{tabular}{|c|c|}
\hline$\Delta \mathrm{F} 508$ homozygous mutation $^{\mathrm{a}}$ & $31 / 79(40 \%)$ \\
\hline Smoker ${ }^{a}$ & $10 / 102(10 \%$ \\
\hline Oxygen supplementation ${ }^{a}$ & 11/95 (11\%) \\
\hline $\mathrm{ABPA}^{\mathrm{a}}$ & $33 / 95(35 \%)$ \\
\hline Exocrine pancreatic insufficiency ${ }^{a}$ & $78 / 102(76 \%$ \\
\hline Diabetes $^{a}$ & $21 / 102(21 \%$ \\
\hline Nasal polyposis $^{a}$ & $25 / 94(27 \%)$ \\
\hline $\mathrm{BMl}, \mathrm{kg} / \mathrm{m}^{2 \mathrm{~b}}$ & $20(20 \pm 3)$ \\
\hline Lean body mass, $\mathrm{kg}^{\mathrm{b}}$ & $45(48 \pm 9)$ \\
\hline Pseudomonas aeruginosa ${ }^{a}$ & $63 / 99(63 \%)$ \\
\hline Staphylococcus aureus $\mathrm{MS}^{\mathrm{a}}$ & $36 / 99(369$ \\
\hline Mycobacterium abscess ${ }^{\mathrm{a}}$ & $4 / 99(4 \%)$ \\
\hline Blood leukocytes, $10^{12} / \mathrm{mm}^{3 \mathrm{~b}}$ & $9(9.7 \pm 3.8)$ \\
\hline Blood polymorphonuclear neutrophils, $10^{12} / \mathrm{mm}^{3 \mathrm{~b}}$ & $6(6.4 \pm 3.3)$ \\
\hline$C R P, m g / L^{b}$ & $5.5(15 \pm 30)$ \\
\hline Serum albumin, $g / L^{b}$ & $42(42 \pm 4)$ \\
\hline
\end{tabular}

Table 2 Resting pulmonary function tests in CF patients classified according to $\mathrm{FEV}_{\mathbf{1}}$

\begin{tabular}{lccc}
\hline & $\begin{array}{c}\text { All patients } \\
(\mathbf{n = 1 0 2})\end{array}$ & $\begin{array}{c}\text { Group 1 } \\
(\mathbf{n = 4 8 )}\end{array}$ & $\begin{array}{c}\text { Group 2 } \\
(\mathbf{n = 5 4})\end{array}$ \\
\hline $\mathrm{FEV}_{1}$ & & $<50 \%$ & $\geq 50 \%$ \\
$\mathrm{FEV}_{1}^{\mathrm{a}}$ & $60 \pm 28$ & $35 \pm 9^{\mathrm{b}}$ & $82 \pm 18$ \\
$\mathrm{FVC}^{\mathrm{a}}$ & $75 \pm 24$ & $56 \pm 14^{\mathrm{b}}$ & $93 \pm 16$ \\
$\mathrm{FEV}_{1} / \mathrm{FVC}$ & $65 \pm 15$ & $54 \pm 11^{\mathrm{b}}$ & $75 \pm 10$ \\
$\mathrm{RV}^{\mathrm{a}}$ & $176 \pm 65$ & $220 \pm 50^{\mathrm{b}}$ & $135 \pm 48$ \\
$\mathrm{DLCO}^{\mathrm{a}}$ & $68 \pm 18$ & $56 \pm 13^{\mathrm{b}}$ & $78 \pm 14$ \\
$\mathrm{PaO}_{2}, \mathrm{~mm} \mathrm{Hg}$ & $80 \pm 14$ & $71 \pm 10^{\mathrm{b}}$ & $87 \pm 12$ \\
$\mathrm{PaCO}_{2}, \mathrm{~mm} \mathrm{Hg}$ & $38 \pm 4$ & $38 \pm 5$ & $37 \pm 4$ \\
$\left.\mathrm{P}^{\mathrm{b}}-\mathrm{a}-\mathrm{a}\right) \mathrm{O}_{2}, \mathrm{~mm} \mathrm{Hg}$ & $29 \pm 13$ & $38 \pm 8^{\mathrm{b}}$ & $21 \pm 12$ \\
\hline
\end{tabular}

${ }^{\mathrm{a}}$ Results are expressed as mean \pm SD percentage of predicted values.

${ }^{\mathrm{b}} P<.0001$ compared with group 2 .

their $\mathrm{FEV}_{1}$ : group 1 patients with severe lung disease $\left(\mathrm{FEV}_{1}<50 \%, 48\right.$ patients) and group 2 patients with mildto-moderate lung disease ( $\mathrm{FEV}_{1} \geq 50 \%, 54$ patients). Group 1 had a significantly higher frequency of homozygosity for the CFTR $\triangle \mathrm{F} 508$ mutation, pancreatic insufficiency, bronchial colonization with Pseudomonas aeruginosa, and biological inflammatory syndrome, and significantly lower body mass index (BMI) and longer disease duration (data not shown).

The patients had a range of disease severities and were recruited from four centers in France. Patients from different centers all had characteristics consistent with the French CF Registry 2009 Report [28] and showed equivalent frequencies of key CF characteristics $(\triangle \mathrm{F} 508$ mutation, exocrine pancreatic insufficiency, and colonization with $P$. aeruginosa), supporting the reproducibility of the results and the potential for extrapolation to other patient populations.

Resting PFT values (Table 2) were significantly more altered in group 1 than in group 2 (Table 2). As expected, three major functional abnormalities were found: obstructive syndrome $\left(\mathrm{FEV}_{1} / \mathrm{FVC}=65 \pm 15 \%\right.$ of predicted), altered distension ( $R V=176 \pm 65 \%$ of predicted), and altered DLCO ( $68 \pm 18 \%$ of predicted).

\section{Exercise responses}

Exercise cessation was mainly due to leg fatigue in combination with dyspnea (62\%), whereas leg fatigue alone or dyspnea alone was observed in $17 \%$ and $21 \%$ of patients, respectively. The $\mathrm{VO}_{2}$ peak value (weight-adjusted $\mathrm{VO}_{2}$ ) was decreased to $<84 \%$ of predicted in $83 / 102$ (82\%) of patients (48/48 [100\%] in group 1 and 35/54 [65\%] in group 2) and was significantly lower in group 1 than in group 2 (Table 3 ).

Analysis of the ventilatory response $\left(\mathrm{V}_{\mathrm{E}}\right.$ peak, $\mathrm{BR}$, respiratory rate (RR), $\mathrm{V}_{\mathrm{T}}$ /FVC peak) highlighted the differences according to $\mathrm{FEV}_{1}$ impairment (Table 3). Group 
Table 3 Cardiopulmonary exercise tests in CF patients classified according to $\mathrm{FEV}_{\mathbf{1}}$

\begin{tabular}{|c|c|c|c|}
\hline & $\begin{array}{l}\text { All patients } \\
(n=102)\end{array}$ & $\begin{array}{l}\text { Group } 1 \\
(n=48)\end{array}$ & $\begin{array}{c}\text { Group } 2 \\
(n=54)\end{array}$ \\
\hline$\overline{\mathrm{FEV}_{1}}$ & & $<50 \%$ & $\geq 50 \%$ \\
\hline $\mathrm{VO}_{2}$ peak, $\mathrm{mL} / \mathrm{kg} / \mathrm{min}$ & $25 \pm 9$ & $20 \pm 5^{d}$ & $30 \pm 8.5$ \\
\hline $\mathrm{VO}_{2}$ peak $^{\mathrm{a}}$ & $65 \pm 21$ & $51 \pm 13^{d}$ & $77 \pm 20$ \\
\hline Borg dyspnea & $4.7 \pm 1.9$ & $5.6 \pm 2^{b}$ & $4.1 \pm 1.5$ \\
\hline Borg Leg fatigue & $4.5 \pm 1.8$ & $5.2 \pm 1.8^{b}$ & $4.4 \pm 1.7$ \\
\hline VE peak, L/min & $58 \pm 22$ & $44 \pm 11^{d}$ & $70 \pm 21$ \\
\hline RR peak, min & $41 \pm 9$ & $43 \pm 9^{b}$ & $39 \pm 8$ \\
\hline$V_{T} / F V C$ peak, \% & $48 \pm 11$ & $47 \pm 13$ & $48.6 \pm 8$ \\
\hline $\mathrm{V}_{\mathrm{E}} \mathrm{NO}_{2}$ peak & $41 \pm 7$ & $42 \pm 7$ & $41 \pm 7$ \\
\hline $\mathrm{V}_{\mathrm{E}} \mathrm{NCO}_{2}$ peak & $36 \pm 6$ & $37 \pm 6$ & $35 \pm 5$ \\
\hline $\mathrm{BR}, \%$ & $24 \pm 20$ & $8 \pm 11^{d}$ & $37.5 \pm 16$ \\
\hline$V_{D} N_{T}$ peak & $0.32 \pm 0.11$ & $0.39 \pm 0.07^{d}$ & $0.25 \pm 0.10$ \\
\hline pH peak & $7.34 \pm 0.04$ & $7.34 \pm 0.04$ & $7.35 \pm 0.04$ \\
\hline $\mathrm{PaO}_{2}$ peak, $\mathrm{mm} \mathrm{Hg}$ & $76 \pm 16$ & $63 \pm 10^{d}$ & $89 \pm 12$ \\
\hline $\mathrm{PaCO}_{2}$ peak, $\mathrm{mm} \mathrm{Hg}$ & $40 \pm 7$ & $44 \pm 6^{d}$ & $36 \pm 4$ \\
\hline $\mathrm{P}(\mathrm{A}-\mathrm{a}) \mathrm{O}_{2}$ peak, $\mathrm{mm} \mathrm{Hg}$ & $37 \pm 13$ & $46 \pm 8^{d}$ & $28 \pm 10$ \\
\hline Lactatemia peak, mmol/L & $7 \pm 2.6$ & $6 \pm 2^{d}$ & $7.9 \pm 3$ \\
\hline HR peak ${ }^{a}$ & $82 \pm 10$ & $79 \pm 8^{d}$ & $86 \pm 9$ \\
\hline $\mathrm{VO}_{2} / \mathrm{HR}$ peak ${ }^{\mathrm{a}}$ & $79 \pm 22$ & $67 \pm 16^{d}$ & $90 \pm 21$ \\
\hline
\end{tabular}

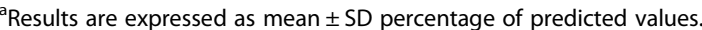

${ }^{\mathrm{b}} \mathrm{P}<.01$ compared with group 2 .

${ }^{c} P<.001$ compared with group 2 .

${ }^{\mathrm{d}} P<.0001$ compared with group 2 .

1 had a lower absolute value of $V_{E}$ at peak exercise, and a depletion of BR. Hyperventilation was due to simultaneous increases in RR and tidal volume. Impairment in pulmonary gas exchange was more severe in group 1 , as shown by higher values of $\mathrm{P}(\mathrm{A}-\mathrm{a}) \mathrm{O}_{2}, \mathrm{~V}_{\mathrm{D}} / \mathrm{V}_{\mathrm{T}}$ peak, and $\mathrm{PaCO}_{2}$, and lower values of $\mathrm{PaO}_{2}$. Cardiocirculatory responses were normal in group 2, but patients in group 1 showed low $\mathrm{VO}_{2} / \mathrm{HR}$ values and a significant decrease in peak HR. Four patients experienced ECG abnormalities but continued with the exercise test.

\section{Determinants of exercise capacity}

Significant correlations were observed between $\mathrm{VO}_{2}$ peak and nutritional status (BMI, lean body mass), inflammation markers (C-reactive protein [CRP], leukocytosis), resting PFT (FVC, FEV $\left.1, \mathrm{RV}, \mathrm{DLCO}, \mathrm{P}(\mathrm{A}-\mathrm{a}) \mathrm{O}_{2}\right)$, and quantifiable parameters of CPET $\left(\mathrm{V}_{\mathrm{E}}\right.$ peak, $\mathrm{V}_{\mathrm{E}} / \mathrm{VO}_{2}$ peak, $\mathrm{V}_{\mathrm{E}} / \mathrm{VCO}_{2}$ peak, $\mathrm{BR}, \mathrm{V}_{\mathrm{D}} / \mathrm{V}_{\mathrm{T}}$ peak, $\mathrm{PaO}_{2}$ peak, $\mathrm{P}(\mathrm{A}-\mathrm{a})$ $\mathrm{O}_{2}$ peak, and $\mathrm{HR}$ (Table 4 and Figure 1).

The results of the stepwise multiple regression analysis for determinants of exercise capacity are shown in Table 5. Of the variables entered into the model (BMI, $\mathrm{FEV}_{1}, \mathrm{FVC}$, DLCO, $\mathrm{PaO}_{2}, \mathrm{~V}_{\mathrm{E}} / \mathrm{VCO}_{2}$ peak, BR, $\mathrm{V}_{\mathrm{D}} / \mathrm{V}_{\mathrm{T}}$ peak, $\mathrm{PaO}_{2}$ peak, $\mathrm{PaCO}_{2}$ peak, $\mathrm{P}(\mathrm{A}-\mathrm{a}) \mathrm{O}_{2}$ peak, and lactatemia peak),
Table 4 Correlation of clinical and functional variables with $\mathrm{VO}_{2}$ peak in CF patients

\begin{tabular}{|c|c|c|c|}
\hline Qualitative variables & $\mathrm{n}$ & & $P$ value \\
\hline Female & 102 & & .22 \\
\hline$\Delta$ F508 homozygous mutation & 79 & & .02 \\
\hline Exocrine pancreatic insufficiency & 102 & & .55 \\
\hline Pseudomonas aeruginosa & 99 & & .36 \\
\hline Quantitative variables & $\mathbf{n}$ & \multicolumn{2}{|c|}{ Correlation (r) } \\
\hline Age, years & 102 & -0.11 & .29 \\
\hline $\mathrm{BMI}, \mathrm{kg} / \mathrm{m}^{2^{*}}$ & 102 & 0.26 & .009 \\
\hline Leukocytosis, $10^{9} / \mathrm{mm}^{3}$ & 70 & -0.42 & .0003 \\
\hline $\mathrm{CRP}, \mathrm{mg} / \mathrm{L}$ & 64 & -0.34 & .006 \\
\hline Serum albumin, $g / L$ & 43 & 0.34 & .02 \\
\hline $\mathrm{FEV}_{1}^{*}$ & 102 & 0.71 & $<.0001$ \\
\hline $\mathrm{FVC}^{\mathrm{a}^{*}}$ & 102 & 0.69 & $<.0001$ \\
\hline $\mathrm{RV}^{\mathrm{a}}$ & 79 & -0.58 & $<.0001$ \\
\hline $\mathrm{DLCO}^{\mathrm{a}}$ & 68 & 0.56 & $<.0001$ \\
\hline $\mathrm{PaO}_{2}, \mathrm{~mm} \mathrm{Hg}$ & 98 & 0.43 & $<.0001$ \\
\hline $\mathrm{PaCO}_{2}, \mathrm{~mm} \mathrm{Hg}$ & 98 & 0.11 & .29 \\
\hline Cardiopulmonary exercise parameters & $\mathbf{n}$ & \multicolumn{2}{|c|}{ Correlation (r) } \\
\hline$V_{E}$ peak, $L$ & 102 & 0.64 & $<.0001$ \\
\hline $\mathrm{V}_{\mathrm{E}} \mathrm{NCO}_{2}$ peak $^{*}$ & 98 & -0.35 & $<.0001$ \\
\hline $\mathrm{BR}, \% *$ & 102 & 0.37 & .0001 \\
\hline$V_{D} N_{T}$ peak $^{*}$ & 96 & -0.64 & $<.0001$ \\
\hline $\mathrm{PaCO}_{2}$ peak, $\mathrm{mm} \mathrm{Hg}{ }^{*}$ & 97 & -0.45 & $<.0001$ \\
\hline $\mathrm{P}(\mathrm{A}-\mathrm{a}) \mathrm{O}_{2}$ peak, $\mathrm{mm} \mathrm{Hg}^{*}$ & 97 & -0.54 & $<.0001$ \\
\hline Lactatemia peak, mmol/L* & 86 & 0.59 & $<.0001$ \\
\hline HR peak ${ }^{a}$ & 102 & 0.40 & $<.0001$ \\
\hline
\end{tabular}

${ }^{a}$ Correlations based on percentage of predicted values. *Selected variables for multivariate stepwise analysis.

only $\mathrm{FEV}_{1}, \mathrm{~V}_{\mathrm{E}} / \mathrm{VCO}_{2}$ peak, and $\mathrm{BR}$ were found to be independent predictors of exercise capacity $\left(r^{2}=0.67\right)$. Analysis of these three variables showed that, for group 1, 31\% of the $\mathrm{VO}_{2}$ peak was explained by $\mathrm{FEV}_{1}$, whereas the major determinants of the $\mathrm{VO}_{2}$ peak in group 2 were $\mathrm{BR}$, $\mathrm{FEV}_{1}$ and $\mathrm{V}_{\mathrm{E}} / \mathrm{VCO}_{2}$ peak (Table 5).

Separate analysis in the cohort of Lille (75 out of the 102 patients) showed the same results: $\mathrm{FEV}_{1}, \mathrm{BR}$ and $\mathrm{V}_{\mathrm{E}} / \mathrm{CO}_{2}$ were independent predictors of exercise capacity $\left(r^{2}=0.65\right)$ (data not shown).

\section{Discussion}

Our study focused on a population of 102 adults with CF who underwent CPET with blood gas analysis at peak exercise. Maximal oxygen uptake was impaired in $82 \%$ of patients and was more pronounced in patients with low $\mathrm{FEV}_{1}$. We noted a high prevalence of abnormal exercise responses in our population, including abnormal gas exchange, ventilatory and cardiocirculatory 

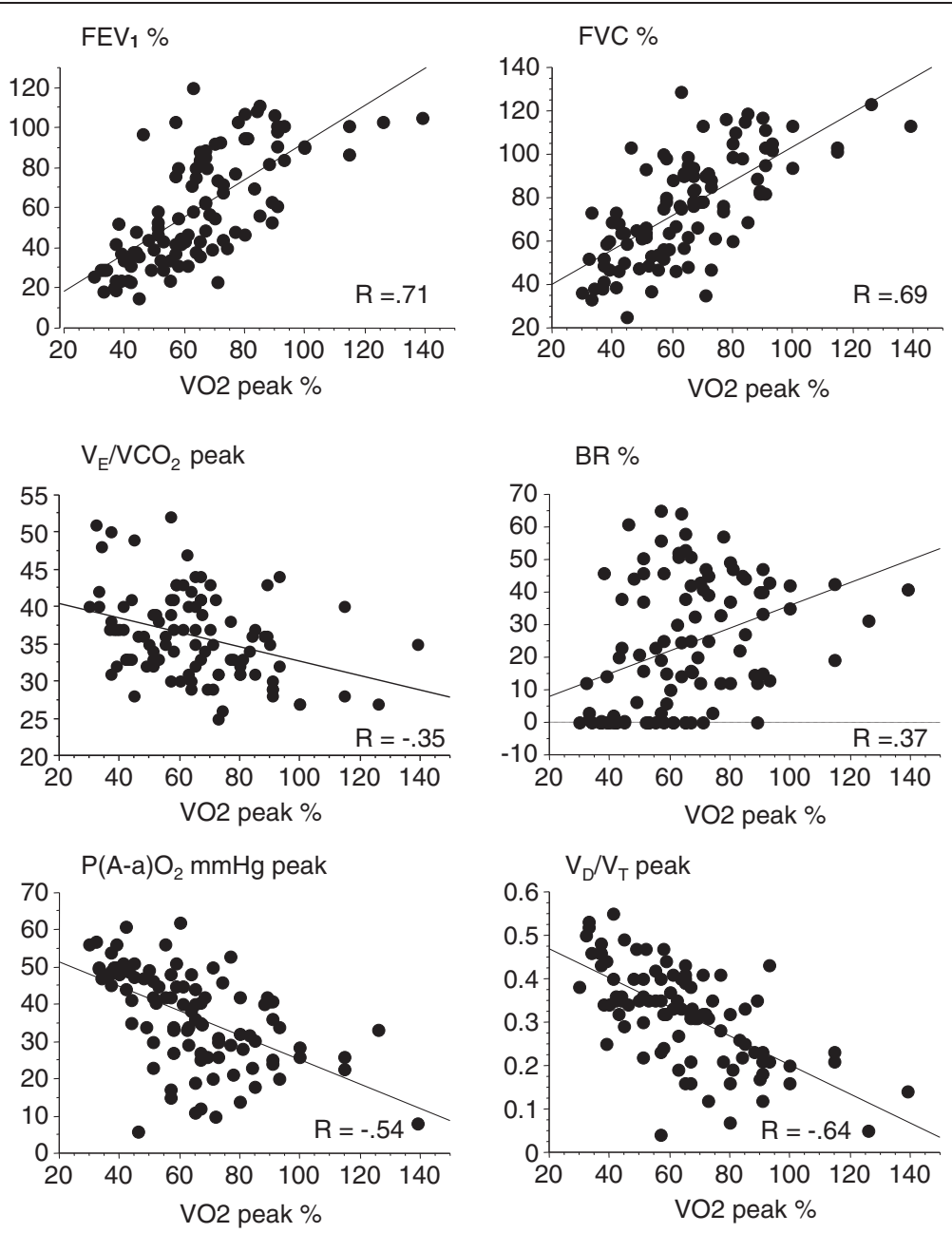

Figure 1 Correlation between $\mathrm{VO}_{2}$ peak and $\mathrm{FEV}_{1}, \mathrm{FVC}, \mathrm{VE} / \mathrm{CO}_{2}$ peak, $\mathrm{BR}, \mathrm{P}(\mathrm{A}-\mathrm{a}) \mathrm{O}_{2}$ peak, and $\mathrm{V}_{\mathrm{D}} / \mathrm{V}_{\mathrm{T}}$ peak in $\mathrm{CF}$ patients. $\mathrm{VO}_{2}$ peak, $\mathrm{FEV}$, $F V C$, and $B R$ are expressed as percentage of predicted values. $\mathrm{P}(\mathrm{A}-\mathrm{a}) \mathrm{O}_{2}$ peak is expressed as $\mathrm{mm} \mathrm{Hg}$.

responses, and peripheral limitation. The main findings from this study are that exercise intolerance in CF is multifactorial and is correlated mainly with resting pulmonary function, nutritional status, and inflammatory status, but is also affected by the magnitude of the overall ventilatory response during exercise. Multivariate analysis revealed that bronchial obstruction plays a dominant role in patients with severe disease, whereas excessive hyperventilation during exercise was the major determinant of exercise limitation in patients with mildto-moderate disease.

CF can be associated with abnormal gas exchange, ventilatory, cardiocirculatory, and muscular responses to exercise $[3,9,13,29]$. In our study, these abnormalities were responsible for limiting the aerobic capacity of $82 \%$ of patients, a proportion consistent with previous studies

Table 5 Determinants of $\mathrm{VO}_{2}$ peak in CF patients

\begin{tabular}{llll}
\hline Variable & $\begin{array}{l}\text { All patients } \\
(\mathbf{n}=\mathbf{1 0 2})\end{array}$ & $\begin{array}{l}\text { Group 1 } \\
(\mathbf{n}=\mathbf{4 8})\end{array}$ & $\begin{array}{l}\text { Group 2 } \\
\mathbf{( n = 5 4 )}\end{array}$ \\
\hline $\mathrm{FEV}{ }_{1}$ & $50(0.84[0.70 ; 0.98])^{\mathrm{a}}$ & $31(1.08[0.70 ; 1.45])^{\mathrm{a}}$ & $18(0.67[0.46 ; 0.88])^{\mathrm{a}}$ \\
$\mathrm{BR}$ & $12(-0.62[-0.82 ;-0.42])^{\mathrm{a}}$ & $6(-0.36[-0.68 ;-0.04])^{\mathrm{b}}$ & $35(-0.85[-1.10 ;-0.59])^{\mathrm{a}}$ \\
$\mathrm{V}_{\mathrm{E}} \mathrm{NCO}_{2}$ peak & $5(-1.13[-1.56 ;-0.69])^{\mathrm{a}}$ & $15(-0.95[-1.41 ;-0.48])^{\mathrm{c}}$ & $6(-1.52[-2.22 ;-0.82])^{\mathrm{a}}$ \\
\hline
\end{tabular}

Results are expressed as the partial $r$-square $\left(r^{2}\right)$, i.e. the percentage of $\mathrm{VO}_{2}$ alteration explained by the variable. Coefficient and $95 \%$ confidence intervals are shown between parentheses. $\mathrm{FEV}_{1}, \mathrm{~V}_{\mathrm{E}} / \mathrm{VCO}_{2}$ peak, and $\mathrm{BR}$ were independent predictors explaining $67 \%$ of exercise capacity $\left(\mathrm{r}^{2}=0.67\right)$. In group $1,31 \%$ of the $\mathrm{VO}_{2}$ peak was explained by $\mathrm{FEV}_{1}$, whereas, in group 2, BR was the major determinant explaining $35 \%$ of the $\mathrm{VO}_{2}$ peak. Results are derived from multivariable analysis.

${ }^{a}$ Adjusted $p$ value $<.0001 ;{ }^{b} p=.027 ;{ }^{c} p=.0002$. 
of adult CF patients $[5,12,30]$. We did not observe a single exercise profile common to all patients, reflecting the complexity of mechanisms involved in exercise limitation in CF patients. Some patients showed abnormalities predominantly in gas exchange, others in the ventilatory response. Still others experienced exercise intolerance despite the absence of ventilatory limitation. The relative contribution of these factors differed between the two groups.

In our study, BMI and CRP levels were strongly correlated with exercise limitation, which is consistent with several studies indicating the importance of inflammatory and nutritional status in exercise limitation. Nutritional status plays a well-established role in CF exercise intolerance [31] and prognosis [32], and may be linked to the chronic inflammation observed in CF patients, which is mainly due to respiratory colonization [33]. Inflammatory markers such as CRP are also negatively associated with exercise capacity in patients with CF [7]. Moreover, inflammation is experimentally correlated with loss of muscle mass [34] and skeletal muscle weakness [10] and could explain the association observed here between CRP, lean body mass, and reduced maximal oxygen uptake.

Multivariate analysis showed that $\mathrm{FEV}_{1}$ was the most significant predictor of $\mathrm{VO}_{2}$ peak in patients with severe lung disease. This result is consistent with data from earlier studies $[3,35]$ and demonstrates the predominant role of ventilatory disorders in exercise limitation in severe CF patients. Additional functional parameters, such as distension, obstruction, and $\mathrm{CO}$ diffusion also correlated with $\mathrm{VO}_{2}$ peak, but were not independent predictors. The low BR exhibited by our population is another characteristic of the exercise response in severe CF patients. Tantisira et al. showed that the BR index $\left(\mathrm{V}_{\mathrm{E}} /\right.$ maximal voluntary ventilation calculated at ventilatory threshold) was the most powerful predictor of mortality in CF patients awaiting lung transplantation [36]. This has also been observed in COPD [37] but is not common to all obstructive lung diseases. For example, McNicholl et al. reported that only $18 \%$ of severe asthma patients had ventilatory limitation due to obstructive lung function [38].

In contrast, the $\mathrm{VO}_{2}$ peak was not fully explained by $\mathrm{FEV}_{1}$ in patients with mild-to-moderate lung disease, and some patients exhibited impaired aerobic capacity despite having normal resting lung function (Figure 1). Indeed, multivariate analysis showed that two CPET parameters were the major independent determinants of $\mathrm{VO}_{2}$ peak in group 2: hyperventilation due to abnormal ventilatory control, resulting in high ventilatory equivalents (as demonstrated by $\mathrm{V}_{\mathrm{E}} / \mathrm{VO}_{2}$ and $\mathrm{V}_{\mathrm{E}} / \mathrm{VCO}_{2}$ peaks), and BR depletion. Exercise ventilation is regulated by numerous mechanisms, most of which remain incompletely understood [39]. Hyperventilation during exercise reflects a nonspecific response to one or more dysfunctional links in the respiratory chain, but the main cause is not known [40]. In some diseases, such as heart failure, hyperventilation is recognized as a more relevant prognostic factor than $\mathrm{VO}_{2}$ peak. The hyperventilatory response may be due to several factors, including inefficient gas exchange as reflected by $\mathrm{P}(\mathrm{A}-\mathrm{a}) \mathrm{O}_{2}$ and the $\mathrm{V}_{\mathrm{D}} / \mathrm{V}_{\mathrm{T}}$ ratio. Although hyperventilation is difficult to relate to other abnormalities, the strong correlation of hyperventilation with oxygen pulse and peak lactatemia suggests that central (cardiovascular) and peripheral (muscle) determinants play a role [10].

In our study, all patients underwent blood gas analysis at peak effort and we noted a high prevalence of gas exchange abnormalities during exercise. It is interesting to note that patients with identical lung function did not all show gas exchange abnormalities. This could be explained by an inadequate ventilatory response in some patients or by a high degree of ventilation-perfusion mismatch. Exercise-induced hypoxemia was common in our study and correlated with $\mathrm{VO}_{2}$ peak, workload, peak $\mathrm{V}_{\mathrm{D}} / \mathrm{V}_{\mathrm{T}}$, and dyspnea assessed by the Borg scale (results not shown). We found that $\mathrm{P}(\mathrm{A}-\mathrm{a}) \mathrm{O}_{2}$ correlated well with peak $\mathrm{VO}_{2}$, highlighting the relevance of this parameter in gas exchange analysis. Other studies have examined impairment of gas exchange during exercise in CF patients. Nixon et al. showed that $\mathrm{P}_{\mathrm{ET}} \mathrm{CO}_{2}>$ $41 \mathrm{~mm} \mathrm{Hg}$ at peak exercise is associated with a twofold higher relative risk of mortality [4]. However, $\mathrm{P}_{\mathrm{ET}} \mathrm{CO}_{2}$ is not a reliable marker for $\mathrm{PaCO}_{2}$ during exercise and does not allow accurate calculation of dead space [41]. Compared with PFT, CPET with blood gas analysis at peak exercise is better able to assess gas exchange abnormalities and highlight exercise hypoxemia, a recognized prognosis marker, and thus gauge the need for oxygen supplementation.

The primary limitation of our study is its retrospective nature and the possibility of missing data. Peripheral muscle strength was not assessed and might be a significant contributing factor [10]. These results should be confirmed by a prospective study.

\section{Conclusion}

In conclusion, exercise limitation in adult patients with $\mathrm{CF}$ correlates with respiratory function as well as nutritional and inflammatory status. This limitation is dependent on $\mathrm{FEV}_{1}$ in patients with severe disease but is mainly affected by the magnitude of the ventilatory response to exercise in patients with mild-to-moderate lung disease. CPET thus contributes to a more comprehensive understanding of exercise limitation and can assist in patient management aimed at improving exercise capacity. 


\section{Competing interests}

For each author, no significant competing interest exists with any companies or organisations whose products or services are mentioned in this article. The authors declare that they have no competing interests.

\section{Authors' contributions}

Conception and design: BW, JP and AP; Analysis and interpretation: BW, JP, $A P, C T, C L$ and $A D$; Drafting the manuscript for important intellectual content: BW, JP, AP, and CL. All authors read and approved the final manuscript.

\section{Acknowledgments}

The authors wish to thank Anne M. O'Rourke for editing of the manuscript. Collaborators (to be referenced in PubMed): T. Perez (Lille), L. Wémeau-Stervinou (Lille), Abderrahmane Mammar (Grenoble), J.M. Perruchini (Dijon).

\section{Author details}

${ }^{1}$ Université Lille 2 et Clinique des Maladies Respiratoires, CRCM Hôpital Calmette, CHRU Lille, France. ${ }^{2}$ Service de Physiologie Respiratoire, CHRU Rouen, France. ${ }^{3}$ Unité de Biostatistiques, CHRU Lille, France.

Received: 28 June 2013 Accepted: 23 April 2014

Published: 30 April 2014

\section{References}

1. Marcotte JE, Grisdale RK, Levison H, Coates AL, Canny GJ: Multiple factors limit exercise capacity in cystic fibrosis. Pediatr Pulmonol 1986, 2:274-281.

2. Boucher GP, Lands LC, Hay JA, Hornby L: Activity levels and the relationship to lung function and nutritional status in children with cystic fibrosis. Am J Phys Med Rehabil 1997, 76:311-315.

3. Lands LC, Heigenhauser GJ, Jones NL: Analysis of factors limiting maximal exercise performance in cystic fibrosis. Clin Sci 1992, 83:391-397.

4. Nixon PA, Orenstein DM, Kelsey SF, Doershuk CF: The prognostic value of exercise testing in patients with cystic fibrosis. N Engl J Med 1992, 327:1785-1788.

5. Moorcroft AJ, Dodd ME, Webb AK: Exercise testing and prognosis in adult cystic fibrosis. Thorax 1997, 52:291-293.

6. Pianosi P, Leblanc J, Almudevar A: Peak oxygen uptake and mortality in children with cystic fibrosis. Thorax 2005, 60:50-54.

7. Van de Weert-van Leeuwen PB, Slieker MG, Hulzebos HJ, Kruitwagen CLJ, van der Ent CK, Arets HGM: Chronic infection and inflammation affect exercise capacity in cystic fibrosis. Eur Respir J 2012, 39:893-898.

8. Bilton D, Dodd ME, Abbot JV, Webb AK: The benefits of exercise combined with physiotherapy in the treatment of adults with cystic fibrosis. Respir Med 1992, 86:507-511.

9. Almajed A, Lands LC: The evolution of exercise capacity and its limiting factors in Cystic Fibrosis. Paediatr Respir Rev 2012, 13:195-199.

10. Troosters T, Langer D, Vrijsen B, Segers J, Wouters K, Janssens W, Gosselink R, Decramer M, Dupont L: Skeletal muscle weakness, exercise tolerance and physical activity in adults with cystic fibrosis. Eur Respir J 2009, 33:99-106.

11. Selvadurai HC, Allen J, Sachinwalla T, Macauley J, Blimkie CJ, Van Asperen PP: Muscle function and resting energy expenditure in female athletes with cystic fibrosis. Am J Respir Crit Care Med 2003, 168:1476-1480.

12. Cerny FJ, Pullano TP, Cropp GJ: Cardiorespiratory adaptations to exercise in cystic fibrosis. Am Rev Respir Dis 1982, 126:217-220.

13. Shah AR, Gozal D, Keens TG: Determinants of aerobic and anaerobic exercise performance in cystic fibrosis. Am J Respir Crit Care Med 1998, 157:1145-1150.

14. Lebecque P, Lapierre JG, Lamarre A, Coates AL: Diffusion capacity and oxygen desaturation effects on exercise in patients with cystic fibrosis. Chest 1987, 91:693-697.

15. Bradley S, Solin P, Wilson J, Johns D, Walters EH, Naughton MT: Hypoxemia and hypercapnia during exercise and sleep in patients with cystic fibrosis. Chest 1999, 116:647-654

16. McKone EF, Barry SC, Fitzgerald MX, Gallagher CG: Role of arterial hypoxemia and pulmonary mechanics in exercise limitation in adults with cystic fibrosis. J App/ Physiol 2005, 99:1012-1018.

17. Marcus CL, Bader D, Stabile MW, Wang Cl, Osher AB, Keens TG: Supplemental oxygen and exercise performance in patients with cystic fibrosis with severe pulmonary disease. Chest 1992, 101:52-57.
18. ATS/ACCP: Statement on cardiopulmonary exercise testing. Am J Respir Crit Care Med 2003, 167:211-277.

19. Stevens D, Oades PJ, Armstrong N, Williams CA: A survey of exercise testing and training in UK cystic fibrosis clinics. J Cyst Fibros 2010, 9:302-306.

20. Miller MR, Hankinson J, Brusasco V, Burgos F, Casaburi R, Coates A, Crapo R, Enright P, van der Grinten CPM, Gustafsson P, Jensen R, Johnson DC, MacIntyre N, McKay R, Navajas D, Pedersen OF, Pellegrino R, Viegi G, Wanger J: Standardisation of spirometry. Eur Respir J 2005, 26:319-338.

21. Macintyre N, Crapo RO, Viegi G, Johnson DC, van der Grinten CPM, Brusasco V, Burgos F, Casaburi R, Coates A, Enright P, Gustafsson P, Hankinson J, Jensen R, McKay R, Miller MR, Navajas D, Pedersen OF, Pellegrino R, Wanger J: Standardisation of the single-breath determination of carbon monoxide uptake in the lung. Eur Respir J 2005, 26:720-735

22. Wanger J, Clausen $J$, Coates A, Pedersen OF, Brusasco V, Burgos F, Casaburi R, Crapo R, Enright P, van der Grinten CPM, Gustafsson P, Hankinson J, Jensen R, Johnson D, Macintyre N, McKay R, Miller MR, Navajas D, Pellegrino R, Viegi G: Standardisation of the measurement of lung volumes. Eur Respir J 2005, 26:511-522.

23. Aguilaniu B, Richard R, Costes F, Bart F, Martinat $Y$, Stach B, Aguilaniu B, Richard R, Costes F, Bart F, Martinat Y, Stach B, Denjean A, Scientific Council of the French Lung Society: [Cardiopulmonary exercise testing]. Rev Mal Respir 2007, 24:2S111-2S160.

24. Wallaert B, Talleu C, Wemeau-Stervinou L, Duhamel A, Robin S, Aguilaniu B: Reduction of maximal oxygen uptake in sarcoidosis: relationship with disease severity. Respiration 2011, 82:501-508.

25. Sorbini CA, Grassi V, Solinas E, Muiesan G: Arterial oxygen tension in relation to age in healthy subjects. Respiration 1968, 25:3-13.

26. Hansen JE, Sue DY, Wasserman K: Predicted values for clinical exercise testing. Am Rev Respir Dis 1984, 129:S49-S55.

27. Sauerbrei W: The Use of Resampling Methods to Simplify Regression Models in Medical Statistics. Journal of the Royal Statistical Society: Series C (Applied Statistics) 1999, 48:313-329.

28. Vaincre La Mucoviscidose. http://www.vaincrelamuco.org/. 2011 Rapport annuel. 2012.

29. Leroy S, Perez T, Neviere R, Aguilaniu B, Wallaert B: Determinants of dyspnea and alveolar hypoventilation during exercise in cystic fibrosis: impact of inspiratory muscle endurance. J Cyst Fibros 2011, 10:159-165.

30. Godfrey S, Mearns M: Pulmonary function and response to exercise in cystic fibrosis. Arch Dis Child 1971, 46:144-151.

31. Gulmans VA, de Meer K, Brackel HJ, Helders PJ: Maximal work capacity in relation to nutritional status in children with cystic fibrosis. Eur Respir J 1997, 10:2014-2017.

32. Nguyen S, Leroy S, Cracowski C, Perez T, Valette M, Neviere R, Aguilaniu B, Wallaert B: Prognostic value of clinical exercise testing in adult patients with cystic fibrosis. Rev Mal Respir 2010, 27:219-225.

33. Van de Weert-van Leeuwen PB, Arets HGM, van der Ent CK, Beekman JM: Infection, inflammation and exercise in cystic fibrosis. Respir Res 2013, $14: 32$

34. Van Heeckeren AM, Tscheikuna J, Walenga RW, Konstan MW, Davis PB, Erokwu B, Haxhiu MA, Ferkol TW: Effect of Pseudomonas infection on weight loss, lung mechanics, and cytokines in mice. Am J Respir Crit Care Med 2000, 161:271-279.

35. Klijn PHC, van der Net J, Kimpen JL, Helders PJM, van der Ent CK: Longitudinal determinants of peak aerobic performance in children with cystic fibrosis. Chest 2003, 124:2215-2219.

36. Tantisira KG, Systrom DM, Ginns LC: An elevated breathing reserve index at the lactate threshold is a predictor of mortality in patients with cystic fibrosis awaiting lung transplantation. Am J Respir Crit Care Med 2002, 165:1629-1633.

37. Medoff BD, Oelberg DA, Kanarek DJ, Systrom DM: Breathing reserve at the lactate threshold to differentiate a pulmonary mechanical from cardiovascular limit to exercise. Chest 1998, 113:913-918.

38. McNicholl DM, Megarry J, McGarvey LP, Riley MS, Heaney LG: The utility of cardiopulmonary exercise testing in difficult asthma. Chest 2011, 139:1117-1123.

39. Dempsey JA: Challenges for future research in exercise physiology as applied to the respiratory system. Exerc Sport Sci Rev 2006, 34:92-98. 
40. Péronnet F, Aguilaniu B: Lactic acid buffering, nonmetabolic $\mathrm{CO} 2$ and exercise hyperventilation: a critical reappraisal. Respir Physiol Neurobiol 2006, 150:4-18.

41. Lewis DA, Sietsema KE, Casaburi R, Sue DY: Inaccuracy of noninvasive estimates of VD/VT in clinical exercise testing. Chest 1994, 106:1476-1480.

doi:10.1186/1471-2466-14-74

Cite this article as: Pastré et al:: Determinants of exercise capacity in cystic fibrosis patients with mild-to-moderate lung disease. BMC

Pulmonary Medicine 2014 14:74.

\section{Submit your next manuscript to BioMed Central} and take full advantage of:

- Convenient online submission

- Thorough peer review

- No space constraints or color figure charges

- Immediate publication on acceptance

- Inclusion in PubMed, CAS, Scopus and Google Scholar

- Research which is freely available for redistribution 